\title{
O CRIME DE ESTUPRO A LUZ DA EPISTEMOLOGIA FEMINISTA: UM ESTUDO DE CASOS NO STF
}

RAPE CRIME IN THE LIGHT OF FEMINIST EPISTEMOLOGY: A CASE STUDY ON THE BRAZILIAN SUPREME COURT

\author{
Lívia de Meira Lima Paiva ${ }^{1}$ \\ IFRJ/RJ \\ Ana Lucia Sabadell ${ }^{2}$ \\ $\mathrm{UFRJ} / \mathrm{RJ}$
}

\section{Resumo}

O presente artigo objetiva o estudo de dois casos paradigmáticos julgados no STF à luz de teorias feministas do Direito. Para tanto, apresentaremos alguns posicionamentos sobre o tema influenciados pelas teorias feministas radical e pósestruturalista. Em seguida, contextualizaremos o Habeas Corpus 73662 e o Recurso Extraordinário 418.376, ambos de autoria do ministro Marco Aurélio de Melo, julgados pelo STF respectivamente em 1996 e 2006. Finalmente, utilizaremos os paradigmas da epistemologia feminista apresentada na primeira parte para uma leitura do discurso jurídico produzido nos casos, elaborando, assim uma análise feminista da formulação do estupro.

Palavras-chaves

Teorias feministas. Epistemologias feministas. HC 73.662. RE 418.376

\section{Abstract}

This article aims to study two paradigmatic cases judged in the STF in the light of feminist legal theories. First of all, we will present some positions on the subject influenced by the radical and poststructuralist feminists theories. Then, we will contextualize the Habeas Corpus n. 73.662 and Extraordinary Appeal n. 418.376, both authored by Minister Marco Aurélio de Melo, judged by the brazilian Supreme

\footnotetext{
${ }^{1}$ Professora do Instituto Federal do Rio de Janeiro, doutoranda em Teoria do Direito na Universidade Federal do Rio de Janeiro.

${ }^{2}$ Professora titular da Universidade Federal do Rio de Janeiro e do Programa de Pós-Graduação em Direito na mesma instituição.
} 
Court respectively in 1996 and 2006. Finally, we will use these paradigms of feminist epistemology presented in the first part to analyse the legal discourse, thus elaborating a feminist analysis of the formulation of the crime of rape.

Keywords

Feminist theories. Feminist epistemology. HC 73.662. RE 418.376

\section{Análise introdutória sobre a violência sexual e seus desdobramentos jurídicos}

A produção de conhecimento acerca do crime de estupro é um dos principais focos das teorias feministas do Direito que se debruçam sobre a análise do sistema de justiça penal, abrangendo o discurso das decisões judiciais e outros fatores sociais que influenciam a prática jurídica neste específico âmbito.

No Brasil, existem poucas pesquisas metodologicamente bem controladas, com produção de dados precisos, sobre a prática deste crime. Especialistas supõem que uma parcela significativa dos estupros sequer chegam ao conhecimento das autoridades. ${ }^{3}$ De todas as formas, investigar a prática de violência sexual constitui sempre um desafio, dada a dificuldade de obtenção de dados.

Ocorre que a ausência de notificação produz a cifra obscura. ${ }^{4}$ Este é um dos principais motivos pelo qual persiste um conhecimento limitado sobre a prática do estupro, principalmente quando praticado na infância e no âmbito das relações amorosas, no marco das relações

${ }^{3}$ Cerqueira, Daniel; Coelho, Danilo Santa Cruz; Ferreira, Helder. 2017., pp.24-48. Texto também disponível em versão eletrônica., cfr. http://www.forumseguranca.org.br/publicacoes/estupro-no-brasil-vitimas-autoresfatores-situacionais-e-evolucao-das-notificacoes-no-sistema-de-saude-entre-2011e-2014/

${ }^{4}$ Sobre o conceito e as dificuldades metodológicas decorrentes, cfr. Sabadell, 2017,pp.61-62; 166 e ss. 
privadas. ${ }^{5}$ Isto ocorre apesar dos esforços realizados para desenvolver métodos mais precisos de estudo da matéria, que permitam superar tais entraves. Portanto, é cientificamente mais "honesto" afirmar que trabalhamos com estimativas.

Neste contexto, muitas pesquisadoras optam por trabalhar com as estatísticas produzidas por órgãos internacionais (ou regionais) de renome, como a ONU ou a OMS. Devemos, porém, recordar que esses organismos internacionais se reportam, para elaborar suas bases de dados, a estudos feitos em nível nacional. De qualquer forma, os problemas de obtenção precisa de dados quantitativos sobre a prática de estupro não foram até hoje solucionados.

Apesar da "parcialidade dos dados", estes são os únicos que nos permitem realizar uma aproximação com a problemática e contribuem, ainda que limitativamente, para levantar o véu da invisibilidade da violência sexual contra o gênero feminino.

Em pesquisas realizadas pela OMS em 2015, a instituição destaca que uma em cada três mulheres latino-americanas foi vítima de violência sexual, ao menos, uma vez em sua vida. Associando esse dado a outros relativos às taxas de assassinatos e práticas de violência

${ }^{5}$ Quando a violência sexual aflige meninas e adolescentes, diminui ainda mais a sua visibilidade. Para uma aproximação com o tema, Cfr. Finkelhor, David. 2009, pp.169-194. Segundo autor, em torno de 30 a $40 \%$ das mulheres norte-americanas informaram, em pesquisas específicas, que foram vítimas de violência sexual na infância. Entre homens esse percentual era em torno de 13\%, ressaltando-se que essa violência nunca ter sido reportada às autoridades competentes. Sobre a dificuldade em detectar a violência sexual no âmbito das relações amorosas entre homens e mulheres, especialistas recordam que a "vergonha" é um sentimento comumente provado pelas vítimas, quando violentadas por seus parceiros. Este fator, associado a outros, tais como a dependência econômica, os vínculos familiares e as consequências para a vida da prole, pesam na decisão em não proceder uma denuncia. Cfr. Entre outros: Weiss, 2010, pp.286-310. Sobre as dificuldades de pesquisar a matéria no Brasil, Cfr. Cerqueira, Daniel; Coelho, Danilo Santa Cruz; Ferreira, Helder. 2017. 
doméstica, a organização conclui que nosso continente vivencia uma verdadeira "epidemia" de violência sexista. ${ }^{6}$

Especificamente sobre o Brasil, o IPEA indicou, em 2014 que, a cada ano, cerca de 527 mil pessoas são vítimas de violência sexual (2014a, p.26). A mesma pesquisa revela que este crime possui características de gênero bem delimitadas: o agressor é (entre 92 e $96 \%$ ) do gênero masculino e a vítima, em $88,5 \%$, pertence ao gênero feminino. ${ }^{7}$

Em outra pesquisa publicada em 2017 - relativa ao período de 2011 a 2014 -, pesquisadores do IPEA analisaram a evolução das notificações de estupro no país, considerando uma base de dados do Ministério da Saúde. Nesse estudo se confirma que na maioria dos casos notificados (69,9\%), as vítimas eram crianças e menores de idade. Também destacam o aumento da prática de estupros coletivos no país. Outro dado importante é que apenas em $25,6 \%$ dos casos o agressor era desconhecido da vítima. Destacam que $40 \%$ dos crimes foi cometido por parentes próximos da vítima (em geral, pai, padrasto, tio, irmão e avô) e o restante, por pessoas conhecidas. ${ }^{8} \mathrm{Ou}$ seja, em $74,4 \%$ dos casos notificados, a vítima conhecia seu agressor. ${ }^{9}$

${ }^{6}$ Estudio multipaís de la OMS sobre la salud de la mujer y violencia doméstica. Organización Mundial de la Salud, Ginebra, 2015. Para consultar os dados sobre o Brasil, vide pp.6-9. (http://apps.who.int/iris/bitstream/10665/43390/1/924359351X_spa.pdf).

${ }^{7}$ As vítimas do sexo masculino, na maioria das vezes, são crianças ou adolescentes, ou seja, possuem algum grau de vulnerabilidade. Isto quer dizer que as taxas de estupro que incidem em adultos do sexo masculino é muito menor.

${ }^{8}$ Cf. Cerqueira, Daniel; Coelho, Danilo Santa Cruz; Ferreira, Helder. 2017.

${ }^{9}$ Estes dados são importantes porque indicam que a avaliação feita nas últimas quatro décadas pelas feministas que se dedicam ao estudo do tema em outros países é também válida (ao menos para os casos notificados) no Brasil. O estuprador é alguém conhecido da vítima, em geral um parente próximo. O lar é o local onde a mulher 
Com relação ao estudo das decisões judiciais em matéria de violência sexual, os problemas metodológicos relativos à quantificação de casos desaparecem. Cotando com uma justiça informatizada e com a "boa vontade" por parte dos órgãos de controle, é possível acessar a dados que nos permitam revelar "como" estamos julgando a violência sexual no país.

Portanto, os problemas que afetam as mulheres em relação ao estudo da violência sexual no âmbito do funcionamento do sistema de justiça penal são de outra ordem. Já há algumas décadas, vários estudos feministas convergem para o entendimento de que a mulher, vítima de violência sexual, é, em geral, discriminada pelo próprio sistema de justiça penal. Isto é, em parte, "esperado", já que estamos analisando um sistema que é parte integrante de uma sociedade machista.

O grande problema é a contradição inerente a uma tal prática jurídica. Se o sistema de justiça elabora normas e dispõe de aparatos que controlam o comportamento das pessoas, visando coibir a prática do estupro, um sistema de justiça penal coerente deveria funcionar "em oposição" à cultura machista, ou seja, deveria combatê-la por meio de suas decisões. ${ }^{10}$ Mas não é isso o que ocorre em diversas partes do mundo. A priori, o sistema que deveria proteger a mulher acaba - em não poucos casos-, submetendo-a a uma lógica de julgamento

corre mais riscos de se submeter a uma violência sexual, sobretudo na infância e a maioria das vítimas pertence ao gênero feminino.

${ }^{10}$ Ciente desta realidade, a organização internacional Women's Link Worldwide criou, com o objetivo de desvendar essa realidade, um "prêmio" (outro, prata e bronze) que é concedido anualmente às sentenças mais sexistas no mundo.

Disponível em: http://www.womenslinkworldwide.org/en/awards Acesso em 10 abr. 2018 
machista. ${ }^{11}$ Não é incomum relato de vítimas de estupro afirmando que a decisão judicial foi uma espécie de "segundo estupro". ${ }^{12}$

É muito comum encontrar decisões judiciais em que o foco de discussão não é a violência sexual sofrida pela vítima (seja esta uma adolescente ou uma mulher adulta), mas o seu comportamento, a sua "moral sexual". Nestes casos, o gênero feminino é submetido a uma segunda vitimização. A primeira é a agressão praticada pelo ofensor e a segunda decorre da forma como a vítima é tratada pelo próprio sistema de justiça. ${ }^{13}$ Em todo caso, existe um evidente "vínculo" entre produção de sentenças sexistas e formulação de leis penais sexistas. ${ }^{14}$

11 Dentre outros estudos: Borkowiski, Margareth; Murch, Mervin; Walker, Val., 1983, pp. 115 e ss. No Brasil, tornou-se um "clássico" a obra publicada por Eluf em 1999, apesar de a autora não se dedicar a uma análise detalhada das sentenças, sua obra deu visibilidade a essa problemática e é referencia para quem deseje conhecer com mais profundidade a jurisprudência machista brasileira. Cfr. Eluf, 1999.

${ }^{12}$ Em outras palavras, o processo "ratifica" a imagem da suposta "cumplicidade" da vítima com a violência por ela sofrida (cfr. por exemplo Smaus 1994, p.p. 86, 89). ${ }^{13}$ Cfr. Sabadell, Ana Lucia. Manual de Sociologia Jurídica. Uma introdução a uma leitura externa do direito. Revista dos Tribunais: São Paulo, 2008, pp. 268-273. Em 2008, 2011, 2013 e 2017 a autora aprofundou o estudo de sentenças proferidas em casos de pedofilia que afetavam meninas, analisando o processo de (re)vitimização. O que se destaca da análise iniciada em 2008 até 2017 é a centralidade deste tipo de discurso nas instâncias superiores da magistratura brasileira, a tendência de reprodução de tais discursos e os subterfúgios adotados para não abandoná-los. Sabadell, 2017 (p.242). Trata-se da desclassificação do estupro de vulneráveis para o art. 65 da Lei de contravenções.

${ }^{14}$ É importante que desde uma perspectiva da sociologia jurídico-penal se realizem estudos mais profundos sobre o papel do gênero na conformação do sistema de justiça penal. Parafraseando o que sustentaram Boswoth e Kaufman no âmbito de seus estudos sobre gênero e sistema punitivo, na sociologia jurídica o gênero ainda se situa em uma perspectiva periférica. As referências ao gênero são feitas de forma complementar, para propiciar uma análise mais ampla de um tema (por exemplo, o papel da mulher como operadora do direito) ou para tratar de problemas muito pontuais, mas os estudos de gênero não conseguiram impactar (e o afirmamos sem 
Na exposição de motivos da reforma da parte geral do código penal (1984), ao descrever as inovações quanto ao tema da Aplicação da pena no âmbito do exame da culpabilidade (núm.50), afirma-se:

Fez-se referência expressa ao comportamento da vítima, erigido, muitas vezes, em fator criminógeno, por constituir-se em provocação ou estímulo à conduta criminosa, como, entre outras modalidades, o pouco recato da vítima nos crimes contra os costumes. ${ }^{15}$

Portanto, o "prévio" exame criminógeno da vítima que é, em primeiro lugar, opção do legislador, integrou o texto do nosso código penal em vigor até 2009.

Nosso objetivo nesse estudo é analisar a violência sexual sob a ótica da teoria feminista radical e pós-estruturalista e vincular essa análise com o estudo de dois casos paradigmáticos, julgados pelo STF, envolvendo estupro de vulneráveis.

Com relação à análise feminista do direito - e que incide sobre nossa análise de casos -, cabe uma prévia observação. Não existe hoje uma única escola de direito feminista. Existem correntes radicais que elaboram fortes críticas à ideologia jurídica dominante, outras de corte mais liberal, que pleiteiam a elaboração de uma reforma do direito de

descuidar da crítica de Butler, pois não há um consenso nas teorias feministas sobre o gênero) os pressupostos epistemológicos nem da Sociologia nem da Sociologia Jurídica e muito menos da Sociologia jurídico-penal. (Bosworth; Kaufman, 2013, p.186.).

${ }^{15}$ Recordamos que a matéria dos crimes sexuais se situavam, em nosso CPB, no título denominado "dos crimes contra os costumes". Cf. Exposição de Motivos № 211, DE 9 de maio de 1983, elaborada pelo Ministro da Justiça Sr. Ibrahim Abi-Ackel. (Da aplicação da Pena, núm.50). Disponível em: http://www2.camara.leg.br/legin/fed/declei/1940-1949/decreto-lei-2848-7dezembro-1940-412868-exposicaodemotivos-148972-pe.html 
modo a propiciar uma tutela mais efetiva dos direitos da mulher e muitas outras, interseccionais, que inserem suas análises em outros contextos de opressões marcantes para mulheres negras ou trans ${ }^{*}$ ou latino-americanas que eram/são invisibilizadas por uma categoria unívoca de "mulheres".

Um dos traços comuns entre as diversas correntes é questionar a própria estrutura do sistema jurídico, produzindo análises que se situam fora do perímetro do direito vigente. A perspectiva feminista buscou criticar a suposta neutralidade dos conceitos jurídicos, desvendando as interpretações masculinas do Direito que as fundamentam.

As feministas radicais desenvolveram os primeiros estudos acerca do estupro considerando-o como um ato motivado pela necessidade de dominação. ${ }^{16} \mathrm{~A}$ ideia de que "todo estupro é um exercício de poder" propõe uma epistemologia que busca o significado do ato à luz do ponto de vista da ofendida, no âmbito da "experiência feminina", expressando a desigualdade existente entre homens e mulheres.

Fundada em um marco teórico pós-estruturalista, a algumas autoras elaboraram críticas à análise feminista radical, em especial à cristalização de uma determinada identidade da mulher através de suas experiências. Ao apontar a experiência feminina como uma fonte de explicação de um evento - ainda que alternativa em uma sociedade patriarcal - as teorias feministas radicais naturalizam determinadas categorias (como homem/mulher, heterossexual/homossexual,

${ }^{16}$ Cfr. As referências em SMAUS Gerlinda. Physische Gewalt und die Macht des Patriarchats, in Kriminologisches JournaP', XXVI, 2, 1994, pp. 82-104. Uma interessante análise histórica sobre a violência sexual, confrontando-a com as concepções sobre liberdade sexual a partir dos anos de 1960 até inícios dos anos 2000, pode ser encontrada em: Barnett, 2004. A obra permite compreender essa mudança na concepção da violência sexual no âmbito dos movimentos feministas. 
sexo/gênero, entre outras), cujos efeitos originais deveriam ser problematizados - e de fato o são por autoras contemporâneas que questionam a ideia de um sistema estável de gênero. ${ }^{17}$

Ainda é necessário situar, em relação ao casos que analisaremos na segunda parte de nosso estudo, que estes foram julgados antes da reforma dos crimes sexuais, datada de 2009. Como se sabe, até o advento da lei 12.015/2009, a prática de cópula com menor de 14 anos era subsumida ao tipo penal de estupro (art. 213 combinado com o art. 224, alínea a), além de ser punida como crime hediondo. ${ }^{18}$ Isto significa que o então art. 224 do Código Penal considerava a violência como presumida e o fazia de forma muito taxativa.

Grande parte da doutrina e da jurisprudência considerava que muitos adolescentes menores de 14 anos mantinham vida sexual ativa e tinham consciência do significado social dos atos sexuais. Por tal motivo, afirmava-se que a presunção de violência deveria ser relativizada em função do comportamento da vítima no caso concreto. Por meio de tal argumentação, foi possível, em uma perspectiva patriarcalista, construir uma jurisprudência sexista que defendia a absolvição de homens que estupraram meninas (ou que mantiveram relação sexual com "consenso"), equiparando-as a mulheres experientes e, às vezes, à prostitutas.

No primeiro, em 1996, o Supremo Tribunal Federal seguiu, por maioria, o voto do relator Ministro Marco Aurélio de Melo no

${ }^{17} \mathrm{Cfr}$., entre muitas outras: Lauretis (1987), Butler (1993, 2001, 1995), Preciado (2014), Haraway (2016).

${ }^{18}$ Como é sabido, a reforma de 2009 estabeleceu essa forma de violência sexual como crime autônomo, de acordo com o disposto no art. 217-A. A pena sofreu uma alteração ( de oito a quinze anos). Assim mesmo, alguns doutrinadores e parte da jurisprudência, relutaram em aceitar essa nova formulação e decisões contra legem foram proferidas inclusive por tribunais de terceira instância. Uma delas gerou um conflito de ordem internacional com a ONU. Para tanto, Cfr. Sabadell, 2017p. 241. 
julgamento do HC 73.662 e considerou que o homem que manteve relações sexuais com menina de 12 anos não praticou estupro porque havia consentimento da menina, que já tinha vida sexual ativa e aparentava idade maior de 14 anos. Isso permitiu ao STF afastar a presunção de violência prevista no revogado art. 224 do Código Penal.

$\mathrm{O}$ segundo caso analisado, também de relatoria do ministro Marco Aurélio de Melo STF, refere-se a uma menina de 9 anos que, em razão das dificuldades financeiras da família, foi entregue pelos pais aos cuidados de uma tia. A menina foi estuprada sistematicamente, pelo tio, seu tutor, que a ameaçava para que não relatasse nada aos familiares. Em 2006 o STF recebe um recurso extraordinário, cuja relatoria fica ao encargo do Ministro Marco Aurélio de Melo. A corte manteve a condenação, mas o relator proferiu um voto (seguido por uma minoria de ministros), onde pleiteava a absolvição do agressor, pois após a gravidez este passou a viver em união estável com a menina. Ademais, alegava que o bem maior a ser preservado seria a família constituída, em especial, pelo "filho" da vítima e do réu, fruto das violações.

\section{A CONFIGURAÇÃO DO CRIME DE ESTUPRO SOB UMA ÓTICA FEMINISTA}

Nesta primeira parte, pretende-se levantar alguns aspectos da tipificação do estupro a partir de uma análise feminista. Ocorre que a própria formulação dos crimes sexuais discrimina a mulher ao mesmo tempo em que favorece a sua (re)vitimização pelo sistema de justiça penal.

Situamos, inicialmente, a legislação brasileira. Entre 2005 e 2009 foram feitas algumas reformas que amenizaram a concepção patriarcalista dos crimes sexuais no país. Entendemos que essas alterações mantém relação com as reformas que foram impulsionadas 
em alguns países europeus, na Austrália e na América do Norte, ainda nos anos de 1990.

Pressionados pelos movimentos feministas, pela abundante produção de estudos feministas nas faculdades de direito e institutos jurídicos, pela presença (ainda que limitada) de mulheres na política e pela produção de tratados internacionais em defesa dos direitos humanos das mulheres, países como Espanha, Itália, Alemanha, Grécia, França, Inglaterra, Austrália, EUA e Canadá reformaram suas legislações penais, absorvendo parte das reivindicações feministas acerca da formulação dos crimes sexuais. ${ }^{19}$

No Brasil esse processo se desenvolve, ainda, com uma certa lentidão. Em 2005 a lei 11.106 revogou alguns tipos penais, como a "Sedução" (art.217), o "Rapto violento ou mediante fraude" e "Rapto consensual" (arts.219 e 220), para os quais era prevista uma diminuição de pena se o agente contraísse matrimônio com a vítima (art. 221). Igualmente foi revogado o dispositivo que previa aumento de pena (atr. 226, III) caso o agressor fosse casado.

Tratava-se de uma formulação sexista dos crimes sexuais, pois a lesão sofrida pela vítima não era objeto principal da tutela do direito. As normas penais não objetivavam proteger a liberdade sexual. Tutelavam, na verdade, uma moral sexista, que situava as mulheres uma posição subalterna, de sujeição ao domínio masculino. Eram normas que apenas protegiam o interesse masculino. Mas isso não foi de todo superado com essa nova abordagem da matéria. Basta lembrar que o próprio título VI - onde se inseriam os delitos sexuais -, permaneceu com a mesma denominação datada de 1940: "Dos crimes contra os costumes". Porém, como veremos a seguir, nem mesmo a reforma de 2009 garantiu um pleno reconhecimento da mulher como sujeito de direitos pelo legislador pátrio.

${ }^{19}$ Para uma análise feminista e comparativa dessas reformas, Cfr.Sabadell, 1999. 
Apesar da supressão das referidas cláusulas de aumento e de diminuição de pena em 2005, em razão de suposto matrimônio (ou de sua impossibilidade) do agressor com a vítima, alguns magistrados continuaram a aplicar o revogado dispositivo, ainda que sem mencioná-lo. O casamento poderia tanto "autorizar" uma diminuição de pena ou até mesmo fundamentar uma sentença absolutória. Analisaremos aqui um Recurso Extraordinário sobre o tema, de relatoria do ministro Marco Aurélio de Melo, onde tal argumento foi empregado com a finalidade de convencer os demais ministros da necessária absolvição de um acusado de praticar pedofilia.

A reforma de 2005 igualmente retirou o termo "mulher honesta", que integrava a descrição dos crimes de "Posse sexual mediante fraude" (art. 215) e "Atentado ao pudor mediante fraude" (art. 216) do CPB. Também neste caso, observou-se que essa supressão não implicou na eliminação (prática) de um juízo de valor negativo, por parte da magistratura, que incide sobre a formulação da sentença criminal na matéria de crimes sexuais. Em nossa análise, nos depararemos com indicativos de que a honestidade das mulheres ainda integra o juízo avaliativo de magistradas e magistrados brasileiros, já que o comportamento sexual das vítimas é critério comumente empregado para absolver réus de crimes sexuais, ${ }^{20}$ mesmo quando as vítimas são crianças ou adolescentes.

Em 2009 ocorre nova reforma e a lei 12.015 altera a formulação do Título VI, que passa a denominar-se "Dos Crimes contra a Dignidade Sexual", situando-se o estupro no capítulo I, denominado "Dos crimes contra a liberdade sexual". Foi uma mudança importante já que os títulos e as denominações dos capítulos refletem, via de regra, os bens jurídicos tutelados pelo legislador. Não mais a tutela de um direito "coletivo" (a moral sexual), mas a tutela de um bem jurídico

${ }^{20}$ Cf. Barbosa;Borges, 2017. 
individual, qual seja, a liberdade sexual da pessoa, posto que o crime lesiona o direito a autodeterminação do exercício da sexualidade.

O mais interessante da reforma de 2009 foi a unificação do denominado "ato libidinoso" com a denominada "conjunção carnal", que resultou na nova formulação do caput do art. 213 do CPB e a formulação autónoma do crime "estupro de vulneráveis" (art. 217-A). Infelizmente, grande parte da doutrina não entendeu a importância da reforma e as discussões giraram em torno da conveniência da unificação dos atos de agressão, se o novo tipo penal era alternativo ou cumulativo. Enfim, a questão central era dirimir como deveria ser aplicado o tipo penal. ${ }^{21}$

A unificação levada a cabo pelo legislador foi uma das mais importantes reivindicações das juristas feministas liberais nos anos de 1990 e foi seguida com atenção pelo legislador italiano e alemão ${ }^{22}$.

Resumidamente, se afirmava que qualquer ato que agrida a autodeterminação sexual da vítima deve ser considerado um estupro. Dessa forma, se abandonava uma tutela fragmentada do corpo feminino (típica da concepção patriarcal). E para respeitar o princípio da proporcionalidade entre injusto penal e a pena prevista no plano abstrato, o que se propunha era que se fizesse uma diferenciação da gravidade da agressão no nível da fixação abstrata da pena. Isto daria uma ampla margem para que a magistratura pudesse aplicar uma pena compatível com a maior, ou menor, lesividade da agressão sexual. Ou seja, a proposta era de tratar de modo minucioso as várias formas de lesão, observando o princípio "nullum crimen sine lege certa”.

\footnotetext{
${ }^{21}$ Nucci, 2014. Entre os discursos sexistas e que demonstram parco conhecimento da dogmática penal alemã em relação à formulação da matéria, prevista no $§ 177$ do StGB, se destaca o artigo de Vicente Greco Filho (Greco Filho, 2009, pp.59-61).

${ }^{22}$ Cfr. Sabadell, 1999. Destacamos que $§ 177$ do código penal alemão foi submetido a outras reformas, a última é datada de 2016, permanecendo unificadas as condutas.
} 
Infelizmente, o legislador brasileiro apenas indicou os casos de lesão corporal de natureza grave, de vítima menor de 18 anos e maior de 14 anos e, aqueles em que ocorresse a morte da vítima ( $§ 1^{\circ}$ e e $\S 2^{2}$ o). Consideramos que isso se deve ao desconhecimento do debate feminista no âmbito da dogmática penal associado aos típicos problemas de técnica legislativa que aflige a legislação penal brasileira (que continuamente desrespeita a lei complementar 95 de 1998).

De todas as formas, a maior parte das reformas (incluindo as realizadas no Brasil) não foram suficientes para superar a concepção patriarcal sobre os crimes sexuais. Indicamos aqui os elementos que impedem uma configuração mais adequada do crime de estupro, centrando-nos, sobretudo, no caso brasileiro.

Um exame da legislação comparada indica que um elemento objetivo dos delitos de "estupro" (e do ab-rogado "atentado violento ao pudor) é constranger a vítima a determinados atos sexuais mediante violência ou grave ameaça. A maioria dos legisladores penais continua empregando essa expressão.

Para citar alguns exemplos, o código penal brasileiro (art. 213ano 2009), colombiano (art. 205 de 2008) ${ }^{23}$, mexicano para o distrito federal (art. 174 de 2002) ${ }^{24}$, o código penal espanhol (art. 178 de

${ }^{23}$ Os crimes sexuais foram objeto de reforma no ano de 2008. O legislador seguiu modelo similar ao espanhol e manteve a distinção entre conjunção carnal e ato libidinoso. Art. 205: El que realice acceso carnal con otra persona mediante violencia, incurrirá en prisión de ocho (8) a quince (15) años.

${ }^{24}$ Art. 174: Al que por medio de la violencia física o moral realice cópula con persona de cualquier sexo, se le impondrá prisión de seis a diecisiete años. Se entiende por cópula, la introducción del pene en el cuerpo humano por vía vaginal, anal o bucal. Se sancionará con la misma pena antes señalada, al que introduzca por vía vaginal o anal cualquier elemento, instrumento o cualquier parte del cuerpo humano, distinto al pene, por medio de la violencia física o moral. Si entre el activo y el pasivo de la violación existiera un vínculo matrimonial, de concubinato o de pareja, se impondrá la pena prevista en este artículo, en estos casos el delito se perseguirá por querella. 
199525), o código penal francês (art. 222-23 de 1989) ${ }^{26}$ e peruano (art. 170 de 2006) ${ }^{27}$, estabelecem - com insignificantes variações terminológicas -, que o meio empregado pelo agente deve ser violência ou grave ameaça. No caso específico do CPB o verbo empregado pelo legislador é "constranger".

Isso indica que o estupro, em uma perspectiva patriarcalista, deve ocorrer de duas formas. A vítima deve "opor" uma forte resistência contra o seu agressor. Se ela não o faz, não se caracteriza a grave ameaça ou violência. ${ }^{28}$

No final do ano de 2013 a desembargadora Bernadete Coutinho Freidrich (Tribunal de Justiça do Rio Grande do Sul) relatou um caso de estupro de uma adolescente de 14 anos e considerou que a violência e a ameaça empregada pelo acusado era fraca (de acordo com os autos ele agarrou a vítima pela cintura, jogou-a em um matagal, ameaçou bater em sua cabeça - caso gritasse - e a imobilizou com seu corpo) e que a vítima poderia ter gritado, mas não o fez. Ademais, a vítima após se encontrar imobilizada, solicitou ao agressor que ao menos usasse um preservativo. Os dados constantes do exame de corpo de delito (hematomas e escoriações no corpo, nas coxas e na genitália) foram considerados irrelevantes. A ausência de uma forte resistência por parte da vítima foi considerada suficiente para "descaracterizar" a

25 Art. 178: El que atentare contra la libertad sexual de otra persona, utilizando violencia o intimidación, será castigado como responsable de agresión sexual (...).Os delitos sexuais foram objeto de diversas reformas na Espanha após 1995, mas permanece o emprego da expressão "violência ou intimidação".

${ }^{26}$ Article 222-23: Tout acte de pénétration sexuelle, de quelque nature qu'il soit, commis sur la personne d'autrui par violence, contrainte, menace ou surprise est un viol. Le viol est puni de quinze ans de réclusion criminelle.

27 Art. 170: El que con violencia o grave amenaza, obliga a una persona a tener acceso carnal por vía vaginal, anal o bucal o realiza otros actos análogos introduciendo objetos o partes del cuerpo por alguna de las dos primeras vías(...).

${ }^{28}$ Sabadell, 1999. 
grave ameaça ou violência. Segundo a desembargadora a violência não "foi tamanha" ao ponto de impedir a vítima de se desvencilhar de seu algoz. ${ }^{29}$ Os demais desembargadores seguiram o voto da relatora e o réu foi absolvido por unaminidade.

Neste contexto, destaca-se que o emprego da expressão "violência ou grave ameaça" exprime a ideia de que a vítima deve expor-se a uma violência ainda maior e "lutar" contra o seu agressor, defendendo, em uma perspectiva sexista, sua "honra sexual" e, se não o faz, isto significa, que o elemento objetivo "grave ameaça ou violência" não se concretiza. Consequentemente, não cabe a subjunção.

As críticas também podem ser estendidas ao emprego do verbo "constranger". Como já foi observado, há situações onde o mero dissenso da vítima constituiu a "única" alternativa que esta tem para expressar seu desacordo com a prática da violência sexual ${ }^{30}$. E muitas vezes a vítima o faz com o objetivo de evitar que a agressão por ela sofrida seja agravada. Ocorre que para demonstrar o constrangimento é preciso expor-se ainda mais a uma potencial agressão. Pense-se

${ }^{29}$ Apelação Crime número 7000521811955- Sexta Câmara Criminal- Tribunal de Justiça do rio Grande do Sul. (publicado no DJ eletrônico 5242 em 20.01.2014). Disponível consulta online: http://www.tjrs.jus.br/busca/search?proxystylesheet=tjrs index\&client=tjrs index \&filter $=0$ \&getfields $={ }^{*} \& a b a=$ juris\&entsp $=\mathrm{a}$ politica$\underline{\text { site } \& w c=200 \& w c \quad m c=1 \& o e=U T F-8 \& i e=U T F-}$

8\&ud=1\&sort=date:D:S:d1\&as qj=\&site=ementario\&as epq=\&as oq=\&as eq=\&req uiredfields=ct:3.crr:496\&partialfields=o:campina.o:das.o:miss\%C3\%B5es.(s:crime)\& as $\mathrm{q}=+$ \&ulang $=\mathrm{pt}-$

BR\&ip $=201.17 .16 .244 \&$ access $=$ \&\&entqr $=3 \&$ entqrm $=0 \& q=+$ inmeta: $a c \% 3 D E s t u p r o \&$ dnavs=inmeta:ac\%3DEstupro\#main res juris. O caso foi recentemente denunciado pela revista GALILEU, (pp.36-37) em matéria inédita na imprensa brasileira sobre decisões machistas dos tribunais brasileiros. Cfr. Galileu, edição 320, março, 2018. ${ }^{30}$ Sabadell,1999; Padovani, 1997. 
também nas situações que envolvem justamente estupro no âmbito familiar, praticado pelo marido ou ex (com filhos presentes em casa), ou praticado pelo pai ou outro parente, casos em que a vítima tem a nítida dificuldade em expressar seu desacordo com a prática sexual. Retomaremos posteriormente esse raciocínio em face da análise dos casos.

Por último, a insistência no emprego das expressões "ato libidinoso" e "conjunção carnal", abolidas por muitos legisladores, indica o forte vínculo que o legislador penal brasileiro mantém com o discurso sexista. Melhor seria que o legislador tivesse empregado um termo mais neutro (praticar atos sexuais), como fez o legislador alemão e, depois, especificasse nos diversos incisos as formas especificas de agressão. ${ }^{31}$

No âmbito acadêmico, como se posicionam as teóricas do feminismo radical e do pós-estruturalismo em face do crime de estupro? As principais críticas, conforme anteriormente mencionado, se iniciam com as posições feministas radicais que inseriam o estupro no âmbito da dominação, questionando uma visão puramente sexual. Catherine Mackinnon (1989) em "Rape: On coercion and consent" problematiza a visão legal de estupro, construída a partir de pressupostos masculinos.

A crítica a esse pensamento será elaborada por feministas pósmodernas que, fundamentadas no pensamento de Michel Foucault, questionam a "experiência feminina" abordada pelas feministas

${ }^{31}$ Essa observação não isenta o tipo penal previsto no § 177 do StGB de críticas, queremos apenas indicar que é possível abdicar do emprego de uma terminologia sexista na formulação da conduta. Para uma leitura sobre a atual configuração do referido artigo após a reforma de 2016, Cf.: Fischer, 2018, pp.1217 e ss. Ressalte-se que apesar das diversas reformas o caput do referido artigo não foi alterado: "Wer gegen den erkennenbaren Willen einer anderen Person sexuellen Handlungen an dieser Person vornimmt oder (...)". 
radicais. Apresentaremos a seguir os dois pensamentos a partir de suas principais autoras.

\subsection{Teoria feminista radical do estupro}

Para Catherine Mackinnon, o estupro não é um evento isolado ou uma transgressão moral individual, mas um ato de terrorismo e tortura com um contexto sistemático de sujeição de um grupo, como o linchamento. De forma geral, as legislações definem "estupro" como uma "relação forçada ou coerção sem consentimento" (intercourse with force or coercion and without consent). Isto quer dizer que uma relação sexual forçada pode ser ou vir a ser sexo, depende do consenso. ${ }^{32}$

Para a autora "com força e sem consentimento", em uma perspectiva feminista, soa redundante, já que a força está presente justamente porque o consentimento está ausente - mas não para a sexualidade submetida a uma supremacia ideológica masculina. A lei é, então, estabelecida em termos do órgão genital masculino, sob um paradigma heteronormativo, onde a penetração cumpre papel essencial para a existência do crime.

Um caso julgado recentemente pelo Tribunal de Justiça do Rio de Janeiro desclassificou o crime de estupro consumado para tentado já que os acusados não percorreram, na opinião dos julgadores o "iter ciminis do seu intento criminoso", que só se concretizaria com a conjunção carnal.

Por outro lado, a prova carreada aos autos evidencia que o delito de estupro restou tentado e não consumado. Ainda que se tenha como suficiente para a configuração do crime em questão a prática de qualquer ato libidinoso, abarcando as mais diversas condutas $i$ desde as

32 MacKinnon, 1989, p. 172. 
mais graves, como penetração anal e vaginal, até condutas menos agressivas, como toques e carícias ¿ é necessário que o agente percorra todo o iter criminis do seu intento criminoso para que se reconheça como consumada a infração penal, o que não se verifica no presente caso. (grifos nossos) ${ }^{33}$

No caso, uma jovem foi sequestrada por pelo menos três homens. A dinâmica foi marcada pelo uso da violência, conforme se aduz do próprio acórdão, mas, de acordo com o entendimento dos desembargadores, posteriormente mantido pelo STJ, o fato da vítima ter fugido antes de uma eventual penetraçãp fez com que o crime não fosse consumado. ${ }^{34}$

De volta ao pensamento de Mackinnon, temos que o corpo da mulher é uma propriedade cujo limite de violação não é dado por ela, mas por um paradigma desigual fundado em uma supremacia masculina: "o homem propõe e a mulher dispõe". A necessidade da

33 Decisão proferida nos autos do processo 0267010-21.2013.8.19.0001.

34 “(...) em local ermo, escuro e com matagal, após desembarcarem com a vítima, puseram-lhe um fio, semelhante a uma linha de pesca, pressionando a região frontal de seu pescoço, jogaram-na no matagal e praticaram com a vítima ato libidinoso, consistente em acariciar seu corpo com fins lascivos. Durante a privação de liberdade, o denunciados (...) continuou a ofender a integridade física da vítima, com emprego de estilete, contando-lhe as pernas, os braços, as costas e sua bermuda, enquanto o denunciado (...) ofendia-lhe a integridade física desferindo chutes, ocasionando as múltiplas agressões as lesões corporais descritas no AECD de fls. 10/11, ainda a ser complementado. Concomitantemente às agressões à vítima, os denunciados faziam uso de substância entorpecente. Assim, aproveitando-se de um momento de distração dos denunciados, enquanto faziam uso da droga, a vítima conseguiu empreender fuga antes que consumassem a conjunção canal, tendo sido socorrida por um taxista que passava pelo local. (...)". 
presença dos elementos como "força/violência" e "sem consentimento" se assemelha mais a uma proibição ao "acesso" da mulher por mais de um homem, ou seja, à monogamia, do que à dignidade sexual da mulher. Nessa perspectiva, no momento em que a mulher consente, ela perdeu essa propriedade.

$\mathrm{O}$ "consentimento" é tido como a forma de controle da mulher sobre o intercurso sexual. À mulher é atribuída a causa da iniciativa masculina e também a negativa de um prazer, quando não há o consentimento. ${ }^{35}$

Um dos maiores desafios é diferenciar o sexo do estupro, o sexo consentido do não consentido. Essa dificuldade de definição abre margem para que elementos culturais operem na interpretação dos fatos realizada pelo julgador. Nesse sentido, é comum observar a (re)vitimação da ofendida, que tem sua vida privada investigada ou forja-se um consentimento presumido, quando, por exemplo, a vítima (antes da agressão sexual) pede uma carona ao agressor ou aceita um primeiro encontro em um bar.

Outro aspecto relevante analisado pelas feministas radicais é a "proliferação" da figura do "estuprador" como alguém monstruoso, dotado de uma moral deturpada e desconhecido da vítima. Estudos revelam o oposto. As mulheres são estupradas, na maioria dos casos, por homens que conheciam (inclusive familiares) e estão mais suscetíveis a serem estupradas do que a estuprarem. ${ }^{36}$

${ }^{35}$ De acordo com estudo recente do IPEA 58,5\% dos entrevistados concordam total ou parcialmente com a seguinte afirmação: "Se as mulheres soubessem como se comportar, haveria menos estupros". Discordam total ou parcialmente da afirmação apenas $37,9 \%$ dos entrevistados. Disponível em: http://www.ipea.gov.br/portal/images/stories/PDFs/SIPS/140327 sips violencia m ulheres.pdf Acesso em 02 mar. 2017

${ }^{36}$ Outra pesquisa do IPEA revela que "no geral, 70\% dos estupros são cometidos por parentes, namorados ou amigos/conhecidos da vítima, o que indica que o principal 
O estupro requer como elemento subjetivo que o acusado atue com dolo, possua uma "mente" criminal (mens rea). As feministas acusam que a formulação do crime é feita segundo um "olhar" estritamente masculino.

Isto requer uma análise sob argumentos que, a princípio, só podem ser parcialmente absorvidos na reflexão sobre a culpabilidade (o que o ato significa para o autor e o que significa para a comunidade?). Interessa refletir sobre o que significa o ato para o autor e para a mulher, mas isso implica em situar a vítima dentro da teoria geral do delito.

O primeiro problema está na significação do estupro, que em muitos casos é uma para o agente da ação e outra para a vítima. No entanto, como standards do crime estão sob um padrão do ofensor, ou seja, masculino (ainda quando construindo "coletivamente" como o olhar da comunidade), "o problema jurídico tem sido determinar qual a visão de que significado constitui o que realmente aconteceu, como se o que aconteceu objetivamente existisse para ser objetivamente determinado". ${ }^{37}$

O segundo problema, derivado do anterior, está no conjunto probatório que deve ser delimitado objetivamente, apesar da oscilação da legislação penal entre testes subjetivos (como por exemplo distinguir sexo de estupro ou o que é um "ato obsceno") e de standards objetivos. Muitas mulheres foram estupradas por homens que sabiam o que o ato deles significava para as vítimas. Em muitos casos, justamente porque "significava" é que estes prosseguiam. Porém, as

inimigo está dentro de casa e que a violência nasce dentro dos lares". Disponível em: https://www12.senado.leg.br/institucional/omv/entenda-a-violencia/pdfs/estuprosno-brasil-uma-radiografia-segundo-os-dados-da-saude Acesso em 25 fev. 2017 37 Tradução nossa. No original: "Interpreted this way, the legal problem has been to determine whose view of that meaning constitutes what really happened, as if what happened objectively exists to be objectively determined”. MacKinnon, 1989, p.181. 
mulheres também são estupradas por homens que não tem ideia do que isso significa para as vítimas. Em linhas gerais, o elemento volitivo é fundamental para a constituição do fato típico, então se o agressor não tinha a intenção ou vontade de constranger a vítima, por mais que a vítima tenha uma visão divergente, não há fato típico.

Para a Mackinnon, a construção do arquétipo do estuprador é a de um homem desconhecido que sabia do não consentimento da vítima e ainda assim escolheu prosseguir com a ação. Quando a lei prevê que a injúria deve ser cognoscível ao agressor, acaba premiando o homem por não saber o significado da sua conduta para a mulher: "hermeneuticamente a lei diz: porque o estuprador não percebeu que a mulher "não o queria", então ela não foi violada". ${ }^{38}$

Assim sendo, a mulher-vítima deve - com risco da lesão de sua própria integridade corporal - resistir "ativamente". Os tribunais não adotam a perspectiva da vítima, ou seja, não tomam em consideração as típicas formas de reação de uma mulher frente a um agressor que, em regra geral, é mais forte que ela e, em todo caso, surpreende a vítima. Deste modo, a intensidade das lesões corporais sofridas tornase o indício principal da "resistência".

Em paralelo, não é considerado decisivo o comportamento da vítima, mas o modo de interpretação da situação pelo agressor, que em geral não "leva a sério" a resistência verbal da vítima. O "macho" que acha que as mulheres desejam um grau de violência (a famosa "vis haud ingrata") será em geral absolvido por erro de tipo. ${ }^{39}$

Com isso, não estamos defendendo que o sistema penal deva adotar a perspectiva da vítima, sob risco de grandes injustiças e contradições, já que compartilhamos da visão de autoras feministas segundo as quais o sistema punitivo, tal como o temos atualmente, é

\footnotetext{
${ }^{38}$ Mackinnon, 1989, p. 181.

${ }^{39}$ Sick, 1991; Kruse;Sczesny, 1993, p.341;345 e ss.
} 
fruto de uma sociedade patriarcal. ${ }^{40}$ Interessa-nos neste estudo apontar as contradições inerentes a este sistema patriarcal que pune severamente alguns crimes (como os patrimoniais e os ligados ao narcotráfico, por exemplo), mas em relação aos crimes de gênero atua com um pseudo garantismo. Neste sentido, um agressor como Roger Abdelmassih acusado de estuprar mais de 40 mulheres tem habeas corpus deferido para responder em liberdade, mas acusados de crimes patrimoniais são considerados ofensores à "ordem pública".

Por isso, situamos nossa análise dentro da Teoria Geral do Delito, para demonstrar como o sistema de justiça opera de forma misógina em muitos casos de violação sexual. Portanto, na

${ }^{40}$ Há muitas décadas criminólogas, filósofas e téoricas do direito feministas iluminam a questão do encarceramento como uma política patriarcal e seus reflexos na reprodução de violências de gênero. Cf., entre muitas outras: Algranti, Leila Mezan. Honradas e Devotas: mulheres da colônia: condição feminina nos conventos e recolhimentos do sudeste do Brasil, 1750-1822. Rio de Janeiro: José Olympio; Brasília: UnB, 1993. Andrade, Vera R. Pereira de. "Violência sexual e sistema penal. Proteção ou duplicação da vitimação feminina?", in: Feminino Masculino. Igualdade e Diferença na Justiça (DeniseDourado Dora, org.). Porto Alegre: Editora Sulina, 1997.

"Criminologia e Feminismo. Da mulher como vítima àmulher como sujeito", Criminologia e Feminismo (CarmenCampos, org.). Porto Alegre: Editora Sulina, 1999. Bierrenbach, Maria Ignês. A mulher presa. Revista doILANUD, n. 12. São Paulo: 1998. Castro, N. E. Hacia una propuesta de equidad de género en el campo penitenciario. In: Bergalli, R. et. al. (orgs.) Violencia y sistema penal. Buenos Aires: Del Puerto, 2008, p. 107-116. Facio, Alda e Camacho, Rosalía. "En busca de las mujeres perdidas o una aproximación crítica a la Criminologia”. In: Vigiladas y Castigadas. Lima: CLADEM, 1993. LARRAURI, Elena. "Control Formal: ...Y el Derecho Penal delas Mujeres". In: Mujeres Derecho Penal y Criminología (Elena Larrauri, org.). Madri: Siglo Veintiuno, 1994. "Criminología Crítica: Abolicionismo y Garantismo", Nueva Doctrina Penal, v. 1998/B. Buenos Aires: Editores delPuerto, 1998. Meo, Analía Inés. "El delito de las féminas", Delito y Sociedad,n. 2. Buenos Aires: 1992. 
culpabilidade o olhar é voltado para o autor, integrando uma leitura subjetivista, devemos considerar:

1. O significado que o ato teve para o autor

2. O signficiado que a comunidade dá ao ato praticado pelo autor.

Agora a contradição, no âmbito de uma Teoria Geral do Delito sexista, é que esse "segundo" exercício de reflexão é feito sob a ótica do império dos machos. Ou seja, sob o império de uma visão machista do signficiado que é dado ao ato pela comunidade. A comunidade, leia-se de passagem, limita-se aos valores propagados pelo homem médio masculino heterossexual.

Parte da doutrina entende que o mero dissenso da vítima é suficiente para caracterizar uma ação sexual ilícita. Por isso, dissemos anteriormente que, de fato, não é raro, nem inexplicável que uma mulher, frente a uma situação de estupro se limite a manifestar ou expressar o seu dissenso. Muitas vezes a mulher atua desta forma na tentativa, mais que legítima, de minimizar o risco de uma violência ainda maior. Em outras palavras, tenta evitar que o agressor empregue meios ainda mais violentos para a consecução do seu ato. E a experiência demonstra que o estupro algumas vezes é praticado em conexão com outros atos de violência, como por exemplo, o femicídio ou lesões corporais graves.

Ademais, como já dissemos no ínicio de nossa reflexão, em inumeráveis casos, em que há um relacionamento social ou afetivo entre agressor e vítima, esta pode não ter a possibilidade (objetiva ou subjetiva) de manifestar uma forte "reação" frente ao mesmo, como expomos anteriormente. Esta é a típica situação de uma dona de casa que é agredida sexualmente pelo marido, com o qual ela mantém interesses vitais (futuro dos filhos, situação de dependência econômica, etc.). 
Uma epistemologia feminista questiona a construção do tipo penal e aponta a falsa pretensão de neutralidade, universalidade e objetividade do Direito. ${ }^{41}$ A linguagem assume um papel fundamental para este questionamento. No estupro, a "perda" da mulher é intangível, dificilmente capturada ou mensurada pelo Direito. A percepção fática da lei estabelece uma verdade que deve ser perseguida e desvendada pelo investigador/julgador.

Nenhuma categoria de análise está livre de uma percepção do sujeito cognoscente. Por isso, uma hermenêutica feminista inclui politicamente este sujeito, retirando sua neutralidade de observador. Não se questiona mais sobre o verdadeiro significado de determinada ação, como se houvesse uma verdade ontológica do fato/ação, mas investiga-se a significação para os diferentes sujeitos em um contexto desigual de gênero.

Neste sentido, a epistemologia feminista proposta pelas feministas radicais busca o significado do ato à luz do ponto de vista da ofendida, na "experiência feminina", expressando a desigualdade existente entre homens e mulheres.

\subsection{Teoria feminista do estupro pós-moderna}

As críticas ao paradigma feminista de Mackinnon são estruturadas especialmente por Carine Mardorossian acerca do estupro. Em "Toward a new feminist theory of rape" a autora busca uma crítica feminista que não aceite premissas existentes e estabeleça "verdades", mas problematize-as fazendo perguntas alternativas e oferecendo diferentes concepções.

${ }^{41}$ Sobre a crítica ao universalismo, neutralidade e objetividade do Direito, cf. Smart, 1992 e Olsen, 1990. 
Enquanto as teorias feministas radicais se preocupam em fornecer mais de um ponto de vista sobre um mesmo evento, as teorias pósmodernas questiona os termos através dos quais a realidade se torna inteligível. ${ }^{42}$ Ao explicar a experiência feminina como uma fonte de explicação de um evento - ainda que alternativa em uma sociedade patriarcal - as teorias feministas radicais cristalizam determinadas categorias (como homem/mulher, heterossexual/homossexual, sexo/gênero, entre outras) cujos efeitos originais deveriam ser problematizados.

De acordo com o pensamento de Michel Foucault ${ }^{43}$, a história do sujeito moderno tem sido uma de despolitização realizada principalmente através da construção de um sujeito psicologizado e ahistórico. A noção do sexo como essência se estrutura especialmente no século XIX, com os discursos médicos, jurídicos, religiosos e sociais que se unem para construir a ideia agora naturalizada do sexo como segredo do ser do indivíduo, ocultando assim o "poder/conhecimento" ou "poder/saber" envolvido nesta concepção.

Uma das filósofas que dialoga diretamente com o pensamento foucaultiano é Judith Butler. Em Problemas de Gênero, a autora propõe que a inteligibilidade de gênero em sociedades contemporâneas passa pela ordem compulsória sexo/gênero/desejo socialmente imposta.

Numa perspectiva pós-estruturalista a ontologia dos gêneros é criticada, pois não há uma essência masculina e outra feminina. $\mathrm{O}$ binarismo (homem/mulher) é um produto reificado de práticas discursivas múltiplas e difusas que funcionam como regimes de produção/construção de poder, cujos elementos definidores são o falocentrismo e a heterossexualidade compulsória. A naturalização das

\footnotetext{
${ }^{42}$ Mardorossian, 2002, p.745.

${ }^{43}$ Foucault, 1978.
} 
categorias é inscrita na linguagem por práticas performativas de gênero como forma de legitimação, que produzem e reproduzem significados socialmente estabelecidos. ${ }^{4}$

Sendo assim, o sexo/gênero "não é um substantivo, mas também tampouco é um conjunto de atributos flutuantes, pois (...) seu efeito substantivo é performativamente produzido e imposto pelas práticas reguladoras de coerência de gênero". Esse questionamento é relevante para as teorias feministas porque ao desestabilizar a categoria de “sexo/gênero" Butler questiona a estabilidade da categoria "Mulheres". 45

${ }^{44}$ A noção de performatividade para Butler pode ser descrita como: “(...) atos, gestos e desejo produzem o efeito de um núcleo ou substância interna, mas o produzem na superfície do corpo, por meio do jogo de ausências significantes, que sugerem, mas nunca revelam, o princípio organizador da identidade como causa. Esses atos, gestos e atuações, entendidos em termos gerais, são performativos, no sentido de que a essência ou identidade que por outro lado pretendem expressar são fabricações manufaturadas e sustentadas por signos corpóreos e outros meios discursivos. O fato de o corpo gênero ser marcado pelo performativo sugere que ele não tem status ontológico separado dos vários atos que constituem sua realidade”. (BUTLER, 2003, p. 194).

${ }^{45}$ A tarefa dessa investigação é centrar-se - e descentrar-se - nessas instituições definidoras: o falocentrismo e a heterossexualidade compulsória. A genealogia toma como foco o gênero e a análise relacional por ele sugerida justamente porque o "feminino" já não parece mais uma noção estável, sendo seu significado tão problemático e errático quanto o de "mulher", e também porque ambos os termos ganham seu significado problemático apenas como termos relacionais. Além disso, já não é mais certo que a teoria feminista deva tentar resolver as questões da identidade primária para dar continuidade à tarefa política. Em vez disso, devemos nos perguntar: que possibilidades políticas são consequência de uma crítica radical das categorias de identidade? Que formas novas de política surgem quando a noção de identidade como base comum já não restringe o discurso sobre políticas feministas? E até que ponto o esforço para localizar uma identidade comum como fundamento para uma política feminista impede uma investigação radical sobre as construções e as normas políticas da própria identidade?”,(Butler, 2003,p. 10). 
A fixação dessas identidades é ilusória dentro do paradigma pósmoderno. As identidades são então pontos de identificação, os pontos instáveis de identificação ou sutura, feitos no interior dos discursos da cultura e da história. A ideia de identidade como origem/essência fora de uma linha ininterrupta dá lugar a ideia de cultura como posicionamento. O significado só pode ser dado de forma arbitrária e contingencial quando interrompida a semiose infinita de significação da linguagem. Esse corte dá sempre uma terminação forçada ao significado, que faz com que ele esteja sempre ou supra ou subdeterminado. ${ }^{46}$

Em "Fighting Bodies, Fighting Words: A Theory and Politics of Rape Prevention" Sharon Marcus (1992) argumenta que a ação política das feministas radicais especialmente na denúncia dos estupros muitas vezes reforça o "roteiro de estupro" que pressupõe o poder masculino e a impotência feminina em que a sociedade inscreve mais ou menos com êxito nas psiques dos homens e das mulheres. Dessa forma, ao afirmar que todo homem heterossexual é um potencial estuprador, cristaliza-se e naturaliza-se um "significante-homem" que detém um "poder" inerente ao seu gênero/sexo. Em outras palavras, o discurso feminista radical inscreve a mulher em um papel social vulnerável e imutável porque é ontológico.

\section{Análise de casos}

Após a apresentação de duas posições feministas divergentes sobre o estupro, analisaremos algumas decisões paradigmáticas sobre o tema. Trazemos à baila alguns indicadores estruturados por Sabadell ${ }^{47}$ que, em consonância com as teorias acima expostas, auxiliam na compreensão das situações de discriminação contra a mulher e também como se (re)produz a violência patriarcal dentro do sistema

\footnotetext{
${ }^{46}$ Hall, 1990.

${ }^{47}$ Sabadell, 2017, p.242-245.
} 
de justiça. São eles: (1) a descaracterização da infância, quando no discurso judicial percebe-se a negativa do status de criança (empregam-se expressões como mocinha, jovem, mulher) (2) a descaracterização do estupro, quando o julgador nega a violência sexual, afirmando ter existido consenso ou alega que o estupro foi apenas uma ação insensata (3) a inversão da condição de vítima, nos casos em que a vítima passa a ser julgada toda vez que se comprove que esta tem vida sexual ativa. (4) a reprodução do discurso patriarcal, quando esses julgados se tornam referência para cortes a quo e (5) a violação do princípio da legalidade penal, quando se percebe analogias ou alegações de erro de tipo, por exemplo, para não seguir a orientação do legislador.

\subsection{Presunção de violência: HC 73662 de 1996}

No Brasil o HC 73662 foi uma decisão paradigmática acerca do crime de estupro de vulnerável. Trata-se de um pedido de soltura do paciente, com base na alegação de que não estava consubstanciado o crime de estupro pelo qual foi acusado (art. 213 c/c o então vigente art. 224 do CP). Primeiramente, para analisar o caso em tela é preciso reestabelecer o contexto do tipo penal de estupro. Somente com a lei 12.015 de 2009 o tipo "estupro de vulnerável" é introduzido no ordenamento brasileiro revogando os dispositivos existentes sobre a presunção de violência e adotando a presunção absoluta de violência.

À época o Código Penal previa a presunção de violência em caso de vítima menor de 14 anos e a mulher como sujeito passivo, conforme já indicamos anteriormente (art. 213 combinado com art. 224, alínea a).

A jurisprudência e doutrina, a partir dos anos de 1990, se dividiam entre a presunção absoluta e relativa. Na primeira, a análise era objetiva: todo ato com menor de 14 anos era considerado violento, sem exceção, fosse estupro (art. 213) ou atentado violento ao pudor 
(art.214), este último revogado pela lei 12.015/09.48 $\mathrm{Na}$ segunda, análise a presunção de violência era relativizada por uma visão subjetiva, pois se observavam as peculiaridades de cada caso, levando em conta diversos fatores como a compleição física da vítima, sua experiência sexual ou as circunstâncias específicas que levaram ao ato sexual.

A presunção relativa adotada pelo STF no caso em análise, embora menos engessada por critérios objetivos como a idade, abriu margem para valorações e visões com incidência de estereótipos de gênero que convergem para um mecanismo já muitas vezes denunciado por feministas no mundo todo: o julgamento da vítima e não do suposto autor do fato.

Um exemplo deste tipo de julgamento é o HC 73662, de relatoria do ministro Marco Aurélio:

\section{ESTUPRO - CONFIGURAÇÃO - VIOLÊNCIA PRESUMIDA - IDADE DA VÍTIMA -}

${ }^{48}$ Destacamos três exemplos da presunção absoluta em julgados: "O consentimento da vítima menor de 14 anos, para a conjunção carnal, e sua experiência anterior não elidem a presunção de violência, caracterizadora do estupro, pois a norma em questão visa, exatamente, a proteção da menor considerando-a incapaz de consentir, não se afastando tal presunção quando a ofendida aparenta idade superior em virtude de seu precoce desenvolvimento físico, ou quando o agente desconhece a idade da vítima”. (STF - HC - Rel. Ilmar Galvão - j. 17.12.1996 - RT 741/566). 2 - Presunção de violência - Vítima menor de 14 anos de idade - "Sequer elide a presunção de violência o alegado fato do consentimento da vítima quanto à relação sexual. A violência ficta, prevista no art. 224, letra a, do Código Penal, é absoluta e não relativa, conforme iterativa jurisprudência do STF. Habeas Corpus indeferido". (STF - 2a T. HC 72.265-5 - Rel. Néri da Silveira - j. 12.12.1997 - DJU 19.11.1999, p. 54). 3 - "O consentimento da menor de quatorze anos para a prática de relações sexuais e sua experiência anterior não afastam a presunção de violência para a caracterização do estupro" (STF - HC 74.580-6 - Rel. Ilmar Galvão - DJU 07.03.1997, p. 5.403). 
NATUREZA. O estupro pressupõe $o$ constrangimento de mulher à conjunção carnal, mediante violência ou grave ameaça artigo 213 do Código Penal. A presunção desta última, por ser vítima menor de 14 anos, é relativa. Confessada ou demonstrada a aquiescência da mulher e exsurgindo da prova dos autos a aparência física e mental, de tratarse de pessoa com idade superior aos 14 anos, impõe-se a conclusão sobre a ausência de configuração do tipo penal. Alcance dos artigos 213 e 224, alínea "a", do Código Penal. (grifo nosso)

O voto do ministro é estruturado pela investigação moral da vítima, cujo depoimento "exsurge com inegável importância". De forma geral, dois são os fatores apontados para a relativização: (1) o fato da vítima já ter mantido relações sexuais com o agressor, que pediu à vítima "gentilmente para que mantivesse conjunção carnal, que se recusara, de início, mas que cedera face às carícias" e (2) a promiscuidade da vítima, que embora a pouca idade, já se comportava de forma lasciva, pois a troca de carícias e beijos também já tinha sido realizada "com amigos do Paciente e outros rapazes". O voto opera uma inversão ao investigar a vida pessoal da vítima como se o fato de já manter relações com o agressor ou de ter um comportamento lascivo com muitos rapazes a fizesse "menos vítima" do que uma "mulher honrada".

Para o ministro, a reputação moral da vítima é mais reprovável do que o ilícito penal:

O quadro se revela estarrecedor, porquanto se constata que menor, contando apenas com doze 
anos, levava vida promíscua, tudo conduzindo à procedência do que articulado pela defesa sobre a aparência de idade superior aos citados doze anos. (...) Precocemente amadurecidas, a maioria delas já conta com discernimento bastante para reagir ante eventuais adversidades, ainda que não possuam escala de valores definida a ponto de vislumbrarem toda a sorte de consequências que lhes pode advir. ${ }^{49}$

Este é o tom do voto declaradamente conservador que decide pelo "anacronismo" do Código Penal face aos tempos atuais, considerando, portanto, a inexistência do ilícito penal, dado não houve, de acordo com o entendimento do ministro, constrangimento ou grave ameaça para obtenção da relação sexual.

Em seguida, por ser menor de 14 anos, o relator passa para a análise da presunção relativa ou absoluta, perquirindo a vida pessoal da ofendida, que parece "aparentar mais idade, levar vida dissoluta, saindo altas horas da noite e mantendo relações sexuais com outros rapazes como reconhecido no depoimento e era de conhecimento público". ${ }^{50}$ Sendo relativa, ela é, então, excluída pelo julgador diante da "suposição equivocada do agente de que a vítima tem idade superior a quatorze anos". ${ }^{51}$

Chama atenção no julgamento, que corria com votação de 3 votos pela absolvição e 2 para a condenação uma "questão de ordem" do ministro Neri da Silveira, então presidente, para que o julgamento, que acontecia na Segunda Turma, fosse enviado ao plenário da Corte,

\footnotetext{
${ }^{49}$ HC 73662, STF, Serviço de Jurisprudência D.J. 20.09.96 ementário número 18422, p. 316

${ }^{50}$ Ibdem. p. 318

${ }^{51}$ Ibdem. p. 319
} 
devido a importância do caso. O ministro Marco Aurélio então, diverge: "Isso gerará perplexidade, tendo em vista que o Impetrante e, também, o meio acadêmico, em virtude da veiculação do caso pelos jornais, pelos periódicos, vêm acompanhando o julgamento com certa expectativa". ${ }^{52}$

Percebe-se da leitura dos votos seguintes, divergente e favoráveis que há um interesse pela mens rea: especula-se a possibilidade de erro de tipo, ao comparar fotos da vítima com de outras meninas mais velhas do que ela e o dolo eventual do agente ao assumir o risco. ${ }^{53}$ Além disso, são acostados aos autos do processo um laudo psicológico somente da vítima, que é citado diversas vezes nos votos de alguns ministros. ${ }^{54}$

O pedido de remessa ao plenário foi denegado pelo mesmo placar de três votos a dois, ficando vencidos o Presidente e o ministro Carlos Velloso. Ressalte-se que à época, como não havia mulheres compondo o Supremo Tribunal Federal, todos os votos foram proferidos por homens.

O dissenso inicial da vítima é citado no voto do relator, mas desconsiderado para fins de análise do delito. Investiga-se, de modo

\footnotetext{
52 Ibdem. p. 339

53 "Não caberia, ademais em habeas corpus, pretender reapreciar as provas do feito criminal, em ordem a poder sustentar a tese de a menor possuir aparência de pessoa com mais de quatorze anos. À evidência, a fotografia de fls. 19, trazida com a inicial, nada prova, desde logo, por absoluta falta de identificação das seis meninas que nela são vistas e da data que corresponde". Ibdem. p. 347

54 "Não é menos certo que, no primeiro depoimento, informou que por medo, subiu na carona da moto do paciente, quando este determinou. Está, de outra parte, em uma rápida incursão pelos documentos, no "laudo psicológico", às fls. 83: "Seu comportamento é instável, com falta de perseverança nas atividades, reagindo de forma imatura às estimulações ambientais. Percebe-se também seu narcisismo e exibicionismo, com fantasias no campo sexual. (...) Encontra-se emocionalmente perturbada, esforçando-se para manter a integridade do ego". Ibdem. p. 353
} 
geral, dois elementos: o elemento volitivo do autor do fato e a moral da vítima. Dessa forma, a verdade jurídica é produzida como espelho da vontade do autor do fato, pois somente interessa o que o fato significou para ele. Em outras palavras, se ele não sabia que a vítima era menor ou se não sabia que ela não consentia, não há estupro. Se, para ele não há estupro, também não há para a lei. Essa passa a ser a única verdade produzida.

\subsection{Equiparação da união estável ao casamento: RE 418.376}

O segundo caso, julgado pelo STF, refere-se a uma menina de 9 anos que, em razão das dificuldades financeiras da família, foi entregue pelos pais aos cuidados de uma tia. A menina foi estuprada sistematicamente, e de forma violenta, pelo tio, seu tutor, que a ameaçava para que não relatasse nada aos familiares. Logo após a primeira menstruação, com 11 anos, a vítima, que continuava sendo seviciada pelo ofensor, engravida.

Em 2006, julgando um recurso extraordinário, o STF manteve a condenação, mas houve uma minoria de ministros que seguiu o voto do Ministro Marco Aurélio, considerando que o ofensor deveria ser absolvido, pois após a gravidez, conforme sugestão do relator, ambos passaram a viver em união estável..$^{55}$

Antes das alterações propostas pela lei 11.106 de 2005 o inciso VII do artigo 107 do Código Penal previa a extinção de punibilidade pelo casamento do agente com a vítima. À época do julgamento este dispositivo não estava mais em vigor, mas beneficiaria o réu, pois quando os crimes foram cometidos ainda vigorava. No Recurso

\footnotetext{
55 Recurso Extraordinário 418.376, relator Ministro Marco Aurélio, julgamento 09.02.2006, Diário de Justiça, 23.03.2007.
} 
Extraordinário em tela, a defesa postulava a equiparação da união estável ao casamento com vistas ao mesmo benefício para o réu.

Art. 107 - Extingue-se a punibilidade:

I - pela morte do agente;

II - pela anistia, graça ou indulto;

III - pela retroatividade de lei que não mais considera o fato como criminoso;

IV - pela prescrição, decadência ou perempção; $\mathrm{V}$ - pela renúncia do direito de queixa ou pelo perdão aceito, nos crimes de ação privada;

VI - pela retratação do agente, nos casos em que a lei a admite;

VII - pelo casamento do agente com a vítima, nos crimes contra os costumes, definidos nos Capítulos I, II e III do Título VI da Parte Especial deste Código; (Revogado pela Lei no 11.106, de 2005)

VIII - pelo casamento da vítima com terceiro, nos crimes referidos no inciso anterior, se cometidos sem violência real ou grave ameaça e desde que a ofendida não requeira $o$ prosseguimento do inquérito policial ou da ação penal no prazo de 60 (sessenta) dias a contar da celebração; (Revogado pela Lei no 11.106, de 2005)

IX - pelo perdão judicial, nos casos previstos em lei.

(grifo nosso) 
Desconsiderando que a vítima era uma criança seviciada pelo agressor e também ignorando o direito vigente (incapacidade de uma criança de 11 anos de consentir ao matrimônio e, por analogia, à união estável), o ministro afirma a possibilidade de uma "analogia in bona partem" no caso:

Quanto ao confronto de valores, cumpre deliberar se o mais importante para o Estado é a preservação da família ou o remédio para a 'ferida social' - causada pelo insensato intercurso sexual - dada a idade da jovem (...). De minha parte, parto da premissa básica - ao Estado cumpre proteger o mais frágil nessa história: o filho que resultou dessa relação. Alfim, será a criança que arcará com as consequências de uma punição pífia, de objetivos no mínimo dúbios: a título de dar satisfação à sociedade, a título de exemplo, acaba-se de solapar a autoestima de uma criança, sobre cujos ombros recairá todo o peso da carga de preconceitos também enfrentada pelo pai 'estuprador' e pela mãe que, após a condenação, transmutar-se- á na companheira de um presidiário, transformado de trabalhador a mero pária, merecedor de todo o opróbio. A quem interessa tanto contrassenso? ${ }^{56}$

Destaca-se a expressão "insensato intercurso sexual" utilizada pelo relator para substituir a palavra "estupro", que em momento

${ }^{56}$ Recurso Extraordinário 418.376, p. 655-656 
algum é sugerido. A divergência ao voto do relator é inaugurada pelo ministro Joaquim Barbosa argumentando que somente o efetivo casamento, regularmente celebrado, tem o condão de extinguir a punibilidade. O posicionamento contrário ao voto do relator é seguido pelo ministro Eros Grau ao afirmar que uma "família que começa com violência contra uma menina de 9 anos - e aparentemente prossegue com mais violência ainda - não é uma família da qual nasce a sociedade civil". O ministro Cezar Peluso acompanha a divergência com a justificativa de que uma criança de 9 anos não possui "consciência" e "discernimento" para avaliar a diferença entre um carinho afetivo e o erótico.

Em outra parte do acórdão a seguinte discussão se estabelece no pleno:

Senhor Ministro Marco Aurélio (Relator) - Pelo que percebi, o agente teria começado a bolinar a garota a partir dos 9 anos e chegou a consumar a relação quando tinha 11 anos. Há também a notícia, na sentença, de que ela própria dissera que antes já se entregara a outro homem. No entanto, isso está na sentença.

Senhor Ministro Joaquim Barbosa Pode-se dar crédito ao que diz uma criança de 9, 10 anos de idade?

Senhor Ministro Sepúlveda Pertence O culpado é sempre a vítima. Acabou a sedução.

(...) Senhor Ministro Marco Aurélio Realmente impressiona - 9 anos -, mas a realidade, principalmente nas classes de menor 


\section{renda, é diversa daquela relativa às classes " $\mathrm{AA}$ ". ${ }^{57}$ (grifos nossos)}

Observa-se que o ministro traz à sua argumentação um fato relativo ao passado da vítima diverso do caso examinado, uma relação sexual com outro homem, para construir uma imagem de menina devassa ou imoral. Ao cabo, conclui, com uma visão classista, como se as crianças de classes mais baixas merecessem uma proteção legal diversa "daquelas relativas às classes 'AA".

Gilmar Mendes, seguindo a mesma linha divergente, apresenta uma "interpretação sistemática" do artigo 226 da Constituição e traz a baila o artigo 227, que versa sobre a responsabilidade do Estado de assegurar a proteção da criança e do adolescente, colocando-os a salvo de negligência, discriminação, exploração, violência, crueldade e opressão.

Por fim, destacamos a manifestação do relator na parte final do acórdão: Não há como colocar esta realidade em segundo plano. A vítima compõe o que se pode, no campo da generalização, denominar de família. Ou seja, o agente provê a subsistência não só da vítima como também do filho nascido, ou filha nascida, e mantém a união estável. Ocorreu, no ano passado, retrocesso normativo ao se alterar o Código Penal para expungir a extinção da punibilidade, em caso de estupro, tenho em vista o casamento.

${ }^{57}$ Ibdem, p. 677 
Indago: interessa à sociedade desfazer, a esta altura, considerado o fato preterido, a união estável existente, condenando o agente a cumprir pena em regime exclusivamente fechado, retirando-o do seio da família, inviabilizando o sustento da própria vítima e do filho nascido? A resposta, para mim, é negativa.

Observo não a circunstância em que foi ocorrido o abuso, o estupro, mas o fato consoante a lei de regência, que deságua na extinção da punibilidade - a união estável. (grifos nossos) ${ }^{58}$

Interessante destacar para esta análise a indagação do ministro acerca do interesse da sociedade na dissolução da "união estável" entre vítima e agressor. Em nenhum momento o magistrado questiona o interesse ou a vontade (por mais que na época da decisão ainda fosse menor de idade) da vítima em manter a relação com seu algoz.

Ao fim, o ministro evidencia que sua análise recai não sobre o fato delituoso "a circunstância em que foi ocorrido o abuso, o estupro", mas sobre um vínculo advindo da violência e de uma suposta obrigação moral de manutenção da família (na figura da união estável). O magistrado, enquanto cidadão, pode até discordar da adequação interna e externa da norma. Mas não pode deixar de aplicá-la, tomando como referência sua opinião. Do contrário, teríamos império de "homens", e não de leis.

Em ambos os casos, o elemento da culpabilidade é o que está em questão. $O$ que $o$ ato significa para quem o pratica, mas especialmente, o que significa para quem o julga? E quem o julga? Nos

${ }^{58}$ Ibdem, p. 694 
votos proferidos pelo ministro Marco Aurélio de Melo o ato não é reprovável e portanto há uma busca para que a culpabilidade seja excluída. Essa investigação ora se dá pela potencial consciência de ilicitude (a vítima tem compleição física de uma menina maior de 14 anos e portanto o agente foi levado ao erro de forma imprevisível) e ora se dá por justificativas morais que autorizam a flexibilizam a penalização.

A abertura para o julgamento subjetivo durante a análise de culpabilidade permite interpretações que reforçam a moral patriarcal vigente na sociedade. A procura por justificativas para a ação delituosa recai sobre a análise moral da vítima, que tem seu passado investigado, em busca de uma escusa para a não aplicação da pena. No exame da culpabilidade, a leitura que a comunidade faz do significado não é neutra. Em muitos casos, como os que analisamos aqui, essa interpretação se realiza através de valores morais hegemônicos em uma sociedade patriarcal. A reflexão que faz o autor e a comunidade sobre o significado da conduta é, portanto, um olhar quase sempre masculino, que além de julgar a mulher-vítima, exclui a possibilidade de sua participação no processo.

\section{CONCLUSÃO}

Os termos "machismo" e "sexismo" podem criar a falsa impressão de que a relação entre homens e mulheres depende apenas da vontade das pessoas, havendo homens "bons", que respeitam as mulheres e homens "ruins" (violentos, arrogantes, possessivos etc.). A teoria feminista indica que essa ideia é falsa. O problema não é a postura individual, mas a cultura que influencia toda a sociedade. Trata-se de uma estrutura social que consiste em uma forma de relacionamento, de comunicação entre os gêneros, caracterizada pela dominação do gênero feminino pelo masculino. 
O patriarcado indica o predomínio de valores masculinos, fundamentados em relações de poder. O poder se exerce por meio de complexos mecanismos de controle social que oprimem e marginalizam as mulheres. A dominação do gênero feminino pelo masculino costuma ser marcada (e garantida) pela violência física e/ou psíquica em uma situação na qual as mulheres (e as crianças) encontram-se na posição mais fraca, sendo desprovidas de meios de reação efetivos.

Este estudo objetivou uma análise de dois casos paradigmáticos de estupro à luz de teorias feministas. Para tanto, apresentamos na primeira parte duas posições. A primeira, radical, expondo a desigualdade entre homens e mulheres, propõe uma epistemologia que busca o significado do ato à luz do ponto de vista da ofendida, na "experiência feminina". A segunda, pós-estruturalista, propõe uma visão que não cristalize papeis fundamentais de gênero, como a identificação da mulher como vulnerável e do homem como um potencial estuprador, apelando sempre para uma análise contingencial.

Em seguida, acrescentamos aos dois posicionamentos indicadores estruturados por Sabadell (2013) que auxiliam na "leitura" das decisões judiciais para identificar possíveis discriminações de gênero e a (re)produção da violência patriarcal dentro do sistema de justiça. A leitura a partir de uma epistemologia jurídica feminista pretende produzir de ambos os casos demonstrou que em diversas ocasiões os ministros - homens e mulheres - se utilizam de estereótipos de gênero e classe social, investigando a vida pessoal da vítima. Observou-se que na argumentação jurídica, elementos como a relação da vítima com o pai ou relacionamentos anteriores da vítima com outros homens são trazidos a baila para tentar diminuir a reprovabilidade do estupro. 
Outra característica evidenciada é a tentativa de descaracterizar a ofendida como criança, trazendo argumentos morais que apelam à precocidade das meninas atualmente, como na linguagem evidenciou-se a utilização de substantivos tais como "moça", "jovem", "menina" e outros recursos linguísticos como a menina "já com 9 anos".

Por fim, em nenhum dos casos o interesse ou a vontade da vítima foi considerada, inclusive quando a decisão versava sobre a possibilidade de manter o relacionamento com seu agressor. Enquanto o voto do ministro Marco Aurélio evidencia o interesse da sociedade na manutenção deste tipo de vínculo, o voto do ministro Gilmar Mendes associa a tutela do bem jurídico violado no caso ao Estado, que tem dever de proteger crianças e adolescentes (em conformidade com o artigo 227 da CF).

Tentamos, neste estudo, apontar as contradições inerentes a este sistema patriarcal que pune severamente alguns crimes (como os patrimoniais e os ligados ao narcotráfico, por exemplo), mas em relação aos crimes de gênero atua com um certo garantismo e flexibilização da lei. Na busca por interpretações que justificam o crime sexual demonstramos como, especilamente na análise de culpabilidade, há forte insidência valores morais hegemônicos em uma sociedade patriarcal que julga, pune e exclui a mulher-vítima.

\section{REFERÊNCIAS}

ALGRANTI, Leila Mezan. Honradas e Devotas: mulheres da colônia: condição feminina nos conventos e recolhimentos do sudeste do Brasil, 1750-1822. Rio de Janeiro: José Olympio; Brasília: UnB, 1993. ANDRADE, Vera R. Pereira de. "Violência sexual e sistema penal. Proteção ou duplicação da vitimação feminina?”, in: 
Feminino Masculino. Igualdade e Diferença na Justiça (DeniseDourado Dora, org.). Porto Alegre: Editora Sulina, 1997.

"Criminologia e Feminismo. Da mulher como vítima àmulher como sujeito", Criminologia e Feminismo (CarmenCampos, org.). Porto Alegre: Editora Sulina, 1999. BIERRENBACH, Maria Ignês. A mulher presa. Revista doILANUD, n. 12. São Paulo: 1998.

BARNETT, Pamela E.: Dangerous Desire: Sexual Freedom and Sexual Violence since the Sixties. Editora Routledge: New York- London, 2004.

BORKOWISKI, Margareth; MURCH, Mervin; WALKER, Val. Marital violence- The community Response. Tavistock Publications: London, 1983.

BOSWORTH, Mary; KAUFMAN, Emma: "Gender and Punishment", In: Jonathan Simon; Richard Sparks (orgs.): The Sage Handbook os Punishment and Society. Editora Sage: Londres, 2013, pp. 186-204 (cap.9).

BARBOSA, Marcela Dias; BORGES, Paulo César Corrêa. Trabalho sexual, estupro e sistema de justiça criminal: uma análise crítica a partir do feminismo de terceiro mundo.In: Revista Eletrônica do Curso de Direito da UFSM, Santa Maria, RS, v. 12, n. 2, p. 387-407, ago. 2017. ISSN 1981-3694. Disponível em: https://periodicos.ufsm.br/revistadireito/article/view/23610/pdf . BUTLER. Judith. Bodies that matter on the discursive limits of "sex". New York \& London: Routledge, 1993.

. Mecanismos Psíquicos del Poder. Teorías sobre la sujeción. Tradución de Jaqueline Cruz. Madri: Ediciones Cátedra, Universitat de Valencia, 2001.

. Problemas de Gênero - Feminismo e Subversão da Identidade - Col. Sujeito \& História. Trad. Renato Aguiar. 8a. ed. Rio de Janeiro: Civilização Brasileira, 2015. 
CASTRO, N. E. Hacia una propuesta de equidad de género en el campo penitenciario. In: BERGALLI, R. et. al. (orgs.) Violencia y sistema penal. Buenos Aires: Del Puerto, 2008, p. 107-116.

CERQUEIRA, Daniel; COELHO, Danilo Santa Cruz; FERREIRA, Helder. Estupro no Brasil: vítimas, autores, fatores situacionais e evolução das notificações no sistema de saúde entre 2011 e 2014. In: Revista Brasileira de Segurança Pública, vol. 11, núm. 1, 2017, pp.2448.

ELUF, Nagib Luiza. Crimes contra os costumes e Assédio Sexual. Doutrina e Jurisprudência. Editora Jurídica Brasileira: São Paulo, 1999. FACIO, Alda e CAMACHO, Rosalía. "En busca de las mujeres perdidas o una aproximación crítica a la Criminologia". In: Vigiladas y Castigadas. Lima: CLADEM, 1993.

FINKELHOR, David. "The Prevention of Childhood Sexual Abuse" in: Future of Children, 2009, 19 ( 2), pp.169-194.

FISCHER, Thomas. Strafgesetzbuch mit Nebengesetzen. C.H.Beck: Berlin, 2018.

FOUCAULT, Michel. The History of Sexuality: An Introduction. Vol. 1. : Random House: New York, 1978.

GRECO FILHO, Vicente. Uma interpretação de duvidosa dignidade (sobre a nova lei dos crimes contra a dignidade sexual). In: Revista do Tribunal Regional Federal da 1ª Região, v. 21, n. 11, nov. 2009 (pp.59$61)$. Disponível em: https://bdjur.stj.jus.br/jspui/bitstream/2011/27392/interpretacao_duvi dosa_dignidade_RTRF1

HALL, Stuart. Cultural identity and diaspora. In: Identity: Community, Culture,Difference. Ed. Jonathan Rutherford. Lawrence \& Wishart: London, 1990.

HANISCH, G. M. Vergewaltigung in der Ehe. Ein Beitrag zur gegenwärtigen Diskussion einer Änderung des $\S 177$ StGB unter 
Berücksichtigung der Strafbarkeit de lege lata und empirischer Gesichtspunkte, Broclemeyer, Bochum, 1988.

HARAWAY. Donna. Manifestly Haraway. Univ Of Minnesota Press; Edição: 1 (1 de abril de 2016).

IPEA. Estupro no Brasil: uma radiografia segundo os dados da Saúde (versão preliminar). Brasília, março de 2014a.

. Tolerância social à violência contra as mulheres. Brasília, 04 de abril de 2014b

KRUSE, K. e SCZESNY, S. Vergewaltigung und sexuelle Nötigung bagatellisierende Auslegung und Scheitern einer Reform. In: Kritische Justiz, 1993

LARRAURI, Elena. "Control Formal: ...Y el Derecho Penal delas Mujeres”. In: Mujeres Derecho Penal y Criminología (Elena Larrauri, org.). Madri: Siglo Veintiuno, 1994.

. "Criminología Crítica: Abolicionismo y Garantismo", Nueva Doctrina Penal, v. 1998/B. Buenos Aires: Editores delPuerto, 1998. LAURETIS, Teresa de. The technology of gender. In: Technologies of gender. Indiana University Press, 1987, pp. 1-30.

MARDORISSIAN, Carine. Toward a New Feminist Theory of Rape. Signs, v. 27, i. 3, p. 743-786, 2002.

MACKINNON, Catharine A. Toward a Feminist Theory of the State. Cambridge, Mass.: Harvard University Press, 1989

MARCUS, Sharon. "Fighting Bodies, Fighting Words: A Theory and Politics of Rape Prevention." In Butler and Scott 1992, 385-404, 1992. MEO, Analía Inés. El delito de las féminas, Delito y Sociedad, n. 2. Buenos Aires: 1992. 
NUCCI, Guilherme. O crime de estupro sob o prisma da Lei 12.015/2009. (artigo disponibilizado pelo autor em seu próprio site). Disponível em: http://www.guilhermenucci.com.br/artigo/o-crimede-estupro-sob-o-prisma-da-lei-12-0152009.

OLSEN, Frances. El sexo Del derecho. In: The Politics of Law (org, David Kairys) Tradução de Mariela Santoro y Christian Courtis, Nova Iorque: Pantheon, pp. 452-467,1990.

PADOVANI, T. I delitti nelle relazioni private, In: L. Violante (org.), Storia d'Italia. Annali 12 (La criminalità), Giulio Einaudi, Torino, p.p. 219-244, 1997.

PATEMAN, Carole. The sexual contract. Stanford, CA: Stanford University. Press, 1988

PRECIADO. Paul B. Manifesto contrassexual: Práticas subversivas de identidade sexual. N1 edições, 2014.

SABADELL, Ana Lucia. A problemática dos delitos sexuais numa perspectiva de direito comparado. In: Revista brasileira de Ciências Criminais, 27, 1999, pp.80-102.

- Manual de Sociologia jurídica. Introdução a uma leitura externa do direito. 4 ed. São Paulo: Revista dos Tribunais, 2008.

- Manual de Sociologia jurídica. Introdução a uma leitura externa do direito. 7 ed. São Paulo: Revista dos Tribunais, 2017.

SMART, Carol. "The woman of legal discourse.". Social and Legal Studies, pp. 37-54, 1992

SMAUS, Gerlinda. 1994. "Physische Gewalt und die Macht des Patriarchats", in: Kriminologisches Journal, vol. 26, núm. 2, pp. 82-104. WEISS, Karen G. Too. Ashamed to Report: Deconstructing the Shame of Sexual Vitimization. In: Feminist Criminology, 5 (3), 2010, pp.286310 . 